\title{
The Mystery of Global Governance
}

\section{Citation}

David W. Kennedy, The Mystery of Global Governance, 34 Ohio N.U. L. Rev. 827 (2008).

\section{Published Version}

http://www.law.harvard.edu/faculty/dkennedy/publications/Kennedy_GlobalGovernance.pdf

\section{Permanent link}

http://nrs.harvard.edu/urn-3:HUL.InstRepos:11222700

\section{Terms of Use}

This article was downloaded from Harvard University's DASH repository, and is made available under the terms and conditions applicable to Open Access Policy Articles, as set forth at http:// nrs.harvard.edu/urn-3:HUL.InstRepos:dash.current.terms-of-use\#OAP

\section{Share Your Story}

The Harvard community has made this article openly available.

Please share how this access benefits you. Submit a story.

\section{Accessibility}




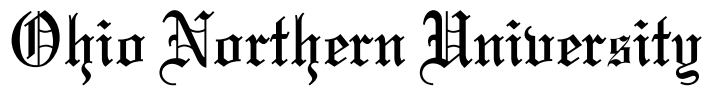 Tiafur helutelur
}

\section{Antêtles}

\section{"The Mystery of Global Governance"}

\author{
DAVID KENNEDY* \\ Kormendy Lecture, Ohio Northern University, Pettit College of Law \\ January 25, 2008
}

\section{How LitTle We KNOW}

Good morning. Across the legal field, people are re-imagining the nature of law outside and among states. And we lawyers are not alone. Our colleagues throughout the social sciences, in economics, political science, sociology, anthropology and more are all thinking anew about global patterns of power and influence.

The simple fact that people are thinking anew is itself of real significance. Significant because it reflects how little we actually know about how we are governed.

Global governance remains a mystery because so much about global society itself eludes our grasp. Everywhere we can see the impact of things global, foreign, far away. How does it all work, how do all the pieces fit together? How is public power exercised, where are the levers, who are the authorities, how do they relate to one another?

Are the worlds of politics, markets and cultural influence held together in a tight structure or is it all more loose and haphazard? Are there more than one global order-how much, in the end, is simply chaos, how much the work of an invisible hand?

\footnotetext{
* University Professor of Law and David and Mariana Fisher University Professor of International Relations, Brown University, and Manley O. Hudson Visiting Professor of Law, Harvard Law School. I am most grateful to Joel Trachtman and Jeff Dunoff for inviting me to present a version of this paper at their "Ruling the World" workshop in December of 2007. The various papers presented at that workshop (including mine) will be published as a collection by Cambridge University Press in the near future.
} 
These questions become urgent when they touch an issue about which we care deeply. How is so much poverty sustained in a world of such plenty? What separates leading from lagging sectors, cultures or nations from one another? How can security be achieved between and within the world's different cultures and nations. If we want to do something about poverty or the environment - if we would like to complain or protest or simply participate - to whom should we address ourselves?

Indeed, how has knowledge about all this itself come to be so unequally distributed? If we understood the machinery by which inequalities and hierarchies of influence and wealth and knowledge are reproduced, we might begin to know how to make the world a better place.

None of these questions have clear answers. We do not know how power is put together on the global stage, let alone how its exercise might be rendered just or effective. Indeed, we are only just beginning to unravel the mystery of global governance. Simply mapping the modes of global power and identifying the channels and levers of influence remains an enormous sociological challenge.

At the same time, we must remember that not that long ago most in the legal profession thought they knew how it all worked. There was private law and public law, national law and international law, each with its own domain. Global governance was the sum of these well known parts, each served by its own disciplinary experts. It is fascinating how quickly that confidence has disappeared and those disciplinary boundaries have broken down.

I would like to think it was partly that decades of critical inquiry were finally rewarded, broke through. But I suspect it was a slowly rising tide of skepticism - accumulated frustration among all those navigating the global political economy with only our routine maps of how the global game is played and where the rules are made.

We may take some comfort that our colleagues in political science and sociology and anthropology and economics were equally confident, if at different moments, and have also had their comeuppance. There were ritualized disputes - realism and constructivism, neo-marginalism and institutionalism, and so on. Yet each of these disciplines thought that, by and large, they had a pretty good sense for how the global picture fit together. As an avid consumer of their work, I must say I would not want to navigate by their maps of world power. Everywhere there is important knowledge, promising new initiatives, intriguing insights. But somehow the broader picture remains elusive.

In part we can blame specialization. Not that long ago, many leading public international lawyers were simply ignorant of international economic law and trade - outside their concern. Internationalists on every faculty had something of the ghetto mentality. Each subfield defended its turf. The study of European law was a rather dramatic example precisely because it arose so 
recently, with tributaries in public international law, national business regulation, constitutional or administrative law and more. But it soon enough became a world of its own.

Disciplinary specialization is not peculiar to lawyers, of course. The American academy of internationalists has all become rather parochial. In political science, the sub-discipline of "international relations" remains an overwhelmingly Ango-American peculiarity. This is partly personnel. A tremendously productive generation of Europeans entered the American legal academy during and after the Second World War-it is difficult to identify their successors or to find voices from other regions of parallel importance in our academy today. But it is also a matter of research agenda. Even the most detailed empirical study of comparative patterns across hundreds of states can hardly help but miss the forest for the trees. Or see the forest in the trees it can measure. The great integrative thinkers of a generation ago seem amateurish, idiosyncratic. But has professionalization deepened our insight? Broadened the scope of our vision?

In economics, the special situations of smaller markets, developing economies, informal economies and black markets and clandestine flows all take second place to the study of interactions among the large post-industrial economic powers. It is no secret that as the economics professoriate professionalized and expanded after the Second World War, they drew the wagons of endogeneity in an ever-tighter circle until much of what anyone would want to know about the patterns of international economic life would need to be learned in exogenous domains relegated to sociology, history, politics and ethics. The pendulum has swung ever so slowly back, but the institutions and political forms and path dependencies brought back within the economics profession remain thin generalizations for the richness of everyday life as it is lived in any economy.

In one after another field, the professionalization of academic knowledge has rendered us blind to what people in other places know. This kind of blind spot is particularly difficult to remedy by interdisciplinary conversation alone, for so many of our disciplines have been purging themselves of knowledge from elsewhere in precisely the same way. Perhaps this is simply one of the costs of a half-century of intellectual, political and economic hegemony. Americans were far more avid importers of scientific ideas a hundred, two hundred years ago when we were living on the periphery of the world system.

At the same time, ideas about economics and law and political affairs developed in the United States have had an enormous impact on the world in the last half century. Unfortunately, we have often been far better at exporting our main ideas than the qualifications and critical traditions with which they arose. And we have imported so little in return. Where in our academic worlds are the great political economists of India or Africa or Latin America-what do we know of them? There are experts in American politics 
and history in China, in Indonesia, in Brazil—how do they teach our history, our ideas?

I have always been struck by the palpable relief among public international lawyers in the North Atlantic that our field weathered the collapse of nineteenth century liberalism, the rise of nationalism, the emergence of international communism, the Soviet Empire, decolonization and the rise of the third world, of Asia, of cultural difference, of feminism and and ... without having to change anything. It is astonishing. The Soviets turned out to be positivists. The Third World loved their sovereignty. All they wanted was a seat on the world court, representation in the international administrative bureaucracies, a little doctrinal change here or there. Everyone could recast their aspirations for justice in the language of universal human rights. Beneath the Islamic, the Hindu, the Christian, the Socialist, the Capitalist traditions lay the same ideas, conveniently spelled out by Eleanor Roosevelt.

\section{WHAT WERE WE THINKING?}

I can report that the situation in Europe was hardly better. From Ireland to Austria, the idea and the institutional machinery of the Europe Union rolled in like a dense fog, foreshortening the horizon of political imagination for an entire generation. If membership is all Europe has to say to its neighbors, what vision does it offer the rest of the world?

For generations young lawyers and policy professionals from across the world have travelled to Europe to learn how their world was made. What did they learn? To pour their humanist aspirations into the most conventional disciplinary categories, rigorously, even passionately. It would be touching, were it not so tragic, to encounter so many well-meant proposals for little imitation European Unions all over the developing world, as if the institutional form appropriate for consolidating the local political and economic power of Europe's post-industrial welfare states would, luckily enough, also be an excellent strategy of economic development for today's Arab or African or Southern Cone regions.

Visiting law faculties in Europe and the United States today, it is striking the extent to which all this has been swept away. I was recently at a workshop in London where more than fifty doctoral students from almost as many countries described their research, their passion, their intellectual agenda. None seemed content with the inherited maps. Innovation, criticism, the aspiration to begin again was everywhere. Where they had come to the center from far away, they had come to learn how it all fell apart- to engage the history of criticism present in the West and the North.

At the same time, in the legal academies of Europe and the United States, specialists in every field - family law, antitrust, intellectual property, civil 
procedure, criminal law, banking and commercial law-have come to see their subject in international or comparative terms. It is hard to think of a legal problem which does not cross disciplinary and national boundaries and it is common for internationalists themselves to stretch across public and private law, to teach about trade and security and development, dipping into national and comparative law as they do. Off the top of my head I can think of numerous inventions that would have been unthinkable just a few years back; I am sure each of you can as well. I know of at least two courses in "international local government law," private law scholars coming out with a legal casebook on comparative Islamic modernization, a new program devoted to the law of empire and colonialism, and on and on.

Part of the explanation is the explosion of voices speaking and writing about international affairs that can now be heard in the intellectual centers of the North and West. The wave of post-colonial thinking, subaltern studies, the re-launching of area studies, the amazing popularity of study abroad, are all part of this trend.

What must it feel like for young intellectuals in Central and Eastern Europe today, entering a world of ideas frozen in political and economic calculations made by those who faced one another across the Rhine more than fifty years ago? Or watching as their elites chew and swallow the thousands of regulations made in the shadow of that vision? Must they content themselves with a kind of permanent intellectual and political marginality, orient themselves to a world whose center is Brussels and for which they can offer only an enduring ethical and political frontier? And what of those new Europeans who are German - and Turkish? Who are French — and African? British - and[?] Or those outside Europe, who find themselves in Turkey or Palestine or Israel and imagine themselves as European? What place for them in the European home?

Something similar is happening in the North American legal academyan invasion of brilliant young legal intellectuals from all over the place. At almost every law school you will find faculty from Kenya or Germany or Mexico. They get tenure the same way, teach the same courses, write in a similar vernacular to their more locally rooted American colleagues and yet their awareness of the blurriness of disciplinary boundaries as they stretch across the planet cannot help but break through, along with all their diverse and complicated emotions about the place of the first world in the third, and the third world in the first. There is something exciting in the idea of the American academy as host for this emerging intellectual diaspora, struggling to comprehend how the world works and how it might be transformed.

Let me begin, then, with preliminary thoughts about moments such as this - moments of both great unknowing and of disciplinary reinvention.

First, it would be surprising if the new order were waiting to be found rather than made. It could be, of course, that our world is already constituted, 
structured, governed, and we simply lack the vision to understand how it works. It seems more plausible, however, to suppose that our conventional understanding has broken down because things in the world are changingChanging rapidly and in all sorts of different directions at once. If there is to be a new order, legal or otherwise, it will be created as much as discovered.

We will need to think of our work on global governance not only as description, but also as program for a world in transition. At the same time, of course, any such program will be but one among many, and will find itself pushed and pulled by the projects and priorities of all the other actors on the field. We will need to think about global governance as a dynamic process, in which legal, political and economic arrangements unleash interests, change the balance of forces, and lead to further reinvention of the governance scheme itself.

I suspect, moreover, that the changes underfoot are likely to swamp our efforts to rethink the world by speaking to one another in rooms like this. Like constitutional orders before it, a new global governance regime will be imagined and built through collective hope, struggle and disappointment. It will be an order made and known through processes we can only dimly see. My only consolation is the intuition - and perhaps the hope - that as the world is re-ordered, law will be there, imagining it, making it, writing it down, consolidating and contesting the new arrangements.

Of course, in the meantime, there is an enormous scholarly premium on being able to see how things will turn out and how they should turn out. It is much less satisfying to seek to understand what is unknown, to identify the powers that elude our grasp, the maps by which it is no longer wise to navigate, the problems for which there is no ready solution, or the solutions long since out of alignment with today's problems. But I am afraid that is where we are. All the rest remains, for the time, a wish.

My second preliminary observation is that knowledge about how we are governed is very unevenly spread about the planet. This is also part, if you like, of how we now find ourselves constituted. We should not be surprised to learn that people in the global North and the global South understand the nature of global power and order quite differently. It is common to imagine that our situations are parallel. One often hears that people in the South know as much as we do about how things work, they simply have different objectives and interests. Or that their knowledge, while different, is equalthey know local things, perhaps cultural things. If we have the luxury to generate theory, they have had the rough luck to inhabit the context where that theory will meet the road. In some sense, this is all certainly true. The insiders and the powerful certainly have their own characteristic blind spots and biases.

But we know the gains from the trade of theory for context are rarely distributed equally. Those in a system's center can sometimes, perhaps even 
quite often, see how the order is ordered, where the levers of power do and do not reside, in ways inaccessible at the periphery. Yes, they can resist, reinvent and appropriate - but so, then, can we, for we are also a context to be reckoned with. I worry about the disequilibria introduced into the governance machinery by the unequal distribution of knowledge. All the more so when educational resources are themselves so unevenly distributed. We all know from our own experience that when you are on the outside looking in, it can seem the powerful know and intend all that they do. When you are on the inside looking out, it is easy to feel buffeted by one thing after another. We will need to find ways to assist the intelligentsia at the margins of the world system in understanding how things look from the center, just as there will be much we will need to learn from them. It is easy to think of this as just educational policy, a matter for the internet and cultural exchange, but it is more. The distribution of knowledge about the global order is also a constitutional issue.

Looking at legal scholarship today, I wonder what has happened to the idea of a "global south?" The idea that there may be a dynamic and structured relationship between leading and lagging industries, economies, ethnic alignments, political powers and intellectual fashions makes it sensible to look for parallels in the experience of all those in the periphery of one or another world system and to see the operations of the center as only part of the story. Indeed, only part of the story of the center's own operation. In my view, this remains an extremely promising idea, particularly as the distance between centers and peripheries shrinks just as the differences between them grows.

We spend far too little energy understanding what happens in between - the conveyor belts by which centers and peripheries are brought into proximity, come to know one another-and to the walls and wills which nevertheless reinforce their differences. We might look for such things in lots of places: in Manchester and Gdansk and Detroit and Mumbai as much as London and Berlin, New York and Hong Kong. But also, I expect, in the hundreds, even thousands of middle cities, exurban sprawls and interlocking networks of informal spaces, free trade zones and all the places where migrants send off remittance. All these places struggle with their insertion into a lurching and volatile international economy, split between numerous centers and peripheries without the umbrella of a national or international public policy able to notice or guarantee their future.

No, knowledge about the ways the world is governed is not spread evenly. It clumps in the centers and spreads unevenly to the periphery. But it is also hoarded in all these middle lands and liminal spaces.

We might say much the same thing about those who live in the worlds of public and private power on the global level. In my own experience, I have certainly found that the corporate lawyers, investment bankers and businessmen of the global economy understand how to operate within a plural and 
disaggregated global legal order far more instinctively than do their counterparts in national government service, diplomacy or the world of international public institutions. In a similar fashion, for all the intense professionalism of our military today, I have found military professionals, including military lawyers, having a far more difficult time thinking strategically about operations in a global battle space stretching across jurisdictions and characterized by wildly divergent interpretations of supposedly common rules and principles than their counterparts in the world of transnational finance or business, for whom legal pluralism is an everyday matter of risk and opportunity.

But here again, we must remember the knowledge that clumps in the middle spaces - the rules of engagement written in the boardrooms of private contractors, rules which will define our national complicity when shots kill. Or the black markets where public and private mingle, the ethnic and religious and humanitarian networks which instrumentalize a public authority here, a private power there which stand outside looking in and infiltrate the operations of formal power.

The unequal distribution of knowledge about the mysteries of global governance calls for more than filling in the gaps in what we know and sharing out what we have learned. The distribution of knowledge about strategic action in a fluid world is also a political, economic and social issue of the first order. That corporate and financial actors move so easily while every public authority is constituted around a territorial jurisdiction as a matter of law has effects. So does the tendency for the middle zones to slip outside the visible forms of public and private power altogether. We ought to see these distributions as constitutional, structuring the forms of our global political life. To comprehend how the world is governed, we must understand the dynamic effects of people living and struggling not only with different interests and cultures and values, but also with different knowledge about how it all works.

Consider this broad brush story. It cannot be told in the vernacular of a discipline. The dynamics of its unfolding are hard to trace in the centers alone. At each stage, the middle spaces were crucial midwifes to new institutional and political forms.

Over the last century, global labor was liberated from serfdom and slavery into citizenship, but incarcerated into one or another nation state. At first, capital was also largely a prisoner of territory. In some places there was an enormous capital shortage and development was difficult, in others a capital abundance and wages rose. As capital became able to move, the price of labor rose wherever development occurred, while capital became relatively scarce where wages remained high. The financial, intellectual and business leaders deracinated themselves, floating freely about the globe. Those at the bottom detached from the formal market and the forms of political life to live 
in an informal world of illegal migration, remittance and black market entrepreneurialism. Meanwhile, politics remained largely the prerogative of national states, lashed to the interests of a territorial middle class. The relative mobility of capital and rigidity of politics rendered each unstable. In the end political and economic leadership has everywhere drifted apart, structurallylinked to different interests, living under different conditions, responding to different constituencies. All this was no accident. Each of these moves was imagined, implemented and resisted in legal terms.

You can get a good sense for this by traveling the world from one "free trade zone" to another, enclaves of informality and exceptions from bureaucratic rule, and then trying to adopt a child abroad or listen for the idea that Americans and Mexicans might share a common political future in the speeches of any American local or national election campaign. All these territorial arrangements and attitudes are underwritten by law and are part of how we are globally governed.

I am not sure how significant this story is or even whether it is altogether correct. I offer it more as a warning. The world's political, economic and social life is legally organized in ways we rarely find the opportunity to notice in routine discussions about global law and governance. We have built fault lines into the political economy of the world and placed forces in motion which will remake the habitual channels of global governance just as we are reaching to understand how it all works.

\section{EARLIER EFFORTS TO RE-IMAGINE THE LEGAL WORLD AND THE WORLD IN LEGAL TERMS}

The world is changing. Our conventional legal picture of the patterns of power is no longer adequate. We need new thinking. Before we get carried away, however, we need to remember that the traditional legal disciplinespublic international law, private international law, international economic law, comparative law, United Nations law - are all also projects of reinvention. Each began both as an effort to draw a more accurate map of the global regime and as a project to remake that regime, in part by re-imagining and redescribing it. Renewal does repeat.

We might say that our first contemporary legal project of re-thinking has been the project, underway for more than twenty years, to write new histories of our conventional fields. To understand what they thought they were renewing and replacing, and how what we have thought about global governance has nevertheless stayed so long so similar. We now have histories which track the origins of contemporary international law not to 1648 or the Roman Empire, but to the mid and late nineteenth century, histories which link our conventional legal disciplines to the imaginative political and ideological projects of particular people, inspired by one or another version 
of European liberalism and legalism, wed to the colonial endeavor, and histories that follow the repeated remaking of these traditions across the twentieth century in bursts of modernist revision. As projects of re-imagination, reconstitution and reform, our conventional disciplines have been pulled this way and that by political and ideological trends which have swept through the society and the academy, perhaps most conspicuously in the last years by feminism and various post-colonialisms, but also by neo-formalism, institutionalism and fads for everything from linguistic to economic analysis.

There remains much we can learn from exploring these conventional projects, although we have lost confidence in them both as maps of the world and as programs for liberal reform. Taken together, their picture of the way the world is governed is striking for its blind spots and biases. The pieces don't fit together or add up. But it remains worth understanding why not and how they could have seemed so coherent for so long. The intellectuals who built them also sought to reconnect the global legal order with the social and psychological forces of their day, to codify that order, to capture it in principles, structure it with new institutions, and treat those new institutions as more than the sum of their parts. We can learn from their ambitions as well as their techniques. Broadly speaking, these were all humanist endeavors, extending what they had learned at home about humanism to the global stage. We can learn from the limitations and possibilities of a century of legal humanism on the world state. Moreover, little that these conventional disciplines set in motion has been lost; it is all there, in fragments, built into this or that corner of our imagination and our institutional fabric. Their ideas and formulations continue to have currency.

If we are to launch a new effort to comprehend the ways our world is governed, I hope we will pause to recall these earlier efforts, if for no other reason than to remind ourselves that whatever we build will rest atop the stillsmoldering ruins of more than a century's worth of efforts to describe in new ways how the world is put together from the point of view, and for the purpose, of governance.

Indeed, even when we move away from the conventional disciplines, we find a history of renewal and reform. In the United States, three projects of re-imagination stand out, each, oddly, associated with a particular University. We might see them as the mothers-of-all-reinventions in the field of global governance. The first was the Yale project on World Public Order, pioneered by Myres McDougal and Harold Lasswell in the nineteen fifties. ${ }^{1}$ Rooted in

1. The literature that I have in mind would include: Myres S. McDougal, Law and Power, 46 AM. J. INT'L L. 102 (1952): Myres S. McDougal, The Comparative Study of Law for Policy Purposes: Value Clarification as an Instrument of Democratic World Order, 1 AM. J. CoMP. L. 24 (1952); Myres S. McDougal, International Law, Power and Policy: A Contemporary Conception, 82 RECUEIL DES COURS 
the sociology and philosophy of the interwar period, their effort cast aside conventional disciplinary boundaries to reconsider the nature of "public order" from the ground up. At the base was not the politics of sovereignty, but neither was there a grundnorm. There were procedures and values, modes of communication, persuasion and compulsion. Everything was on a continuum, anti-formal, requiring judgment and human ethical choice. Elites inhabited a policy process in which they would as often make as follow the law. Global governance was a work in progress, a terribly serious business, neither irrational politics nor rational law, but an ongoing project to choose a world public order of freedom and justice.

The second was something of a reaction, an alternative found for a generation in Manhattan, at Columbia and NYU, and associated with in an astonishing group of figures: Franck, Friedmann, Henkin, Schachter and their many colleagues. ${ }^{2}$ They were as anti-formal and post-realist as Yale, but their

133 (1953); Myres S. McDougal, Peace and War: Factual Continuum With Multiple Legal Consequences, 49 AM. J. INT'L. 63 (1955); Myres S. McDougal, The Realist Theory in Pyrrhic Victory, 49 AM. J. INT'L. 376 (1955); Myres S. McDougal, Some Basic Theoretical Concepts About International Law: A PolicyOriented Framework of Inquiry, 4 J. CONFLict Resolution 337 (1960); Myres S. MCDougal \& Associates, Studies IN World Public Order (Yale Univ. Press 1960); Myres S. McDougal and WiLLIAM T. BURKE, THE PUBLIC ORdER OF THE OCEANS: A CONTEMPORARY INTERNATIONAL LAW OF THE Seas (Yale Univ. Press 1962); Myres S. MCDougal and Florentino P. Feliciano, LaW AND Minimum

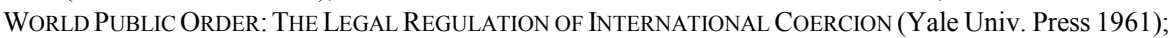
Myres S. McDougal and Harold D. Lasswell, The Identification and Appraisal of Diverse Systems of Public Order, 53 Am. J. Int'L L. 1 (1959); Myres S. McDougal, Harold D. LASSWEll \& Lung-CHU Chen, Human Rights And World Public Order (Yale Univ. Press, 1980); Myres S. McDougal, Harold D. LASSWELl \& JAMES C. Miller, THE INTERPRETATION OF AgREEMENTS AND WORLD Public ORdeR: Principles of Content and Procedure (Yale Univ. Press 1967); Myres S. McDougal, Harold D. Lasswell \& Ivan A. Vlasic, Law and Public Order In Space (Yale Univ. Press 1963); Myres S. McDougal and W. Michael Reisman, The Changing Structure of International Law: Unchanging Theory for Inquiry, 65 COLUM. L. REV. 810 (1965); RICHARD A. FALK, LAW, MORALITY AND WAR IN THE CONTEMPORARY World (Praeger 1963); Richard A. FalK, THE ROLE OF DOMESTIC COURTS IN THE International Legal Order (Princeton Univ. Press 1964): Richard A. FalK, Legal Order IN A Violent World (Princeton Univ. Press 1968); Richard A. FALK, The STATUS OF LAW In INTERNATIONAL SOCIETY (Princeton Univ. Press 1970), Richard A. Falk, A New Paradigm for International Legal Studies: Prospects and Proposals, 84 Yale L. J. 969 (1975); Rosalyn Higgins, The Development of International Law Through the Political Organs of the United Nations (Oxford Univ. Press 1963); Rosalyn Higgins, Policy Considerations and the International Judicial Process, 17 INT'L \& CoMP. L. Q. 58 (1968) ); Rosalyn Higgins, Policy and Impartiality: The Uneasy Relationship in International Law, 23 InT'L ORg. 914 (1969); Morton A. KaPlan \& Nicholas Deb. KaTZEnBaCh, The Political FOUNDATIONS OF INTERNATIONAL LAW (Wiley 1961); W. MiCHAEL REISMAN, NulLITY AND REVISION: THE REVIEW AND ENFORCEMENT OF INTERNATIONAL JUDGMENTS AND AWARDS (Yale Univ. Press 1971). See also TOWARd World Order and Human Dignity: EsSAYs In HonOR OF MYres S. MCDOUgal (W. Michael Reisman \& Burns H. Weston eds., Free Press 1976); The Structure AND Process of InTERnational LaW: Essays in Legal Philosophy, Doctrine, AND TheORY (R. St. J. Macdonald and Douglas M. Johnston eds., Kluwer Boston 1983).

2. Particularly notable contributions include: Thomas M. Franck, The Courts, the State Department 
emphasis was different. Rules seemed more necessary to restrain the Cold War great powers. The United Nations loomed large, the Charter providing at once a set of restraints, a venue for multilateralism, and a ready vernacular and perspective for the legitimation and delegitimation of national power. For the Manhattan School, global governance was to be as much a work of the spirit, a work on the self, as a structure of rules and institutions. Most famously, perhaps, for Louis Henkin, the human rights regime matured into a global "ideology," common to elites everywhere, limiting and channeling the exercise of public power automatically, without the machinery of enforcement. If he was right, Holmes and Hohfeld had been defeated. It was not all about remedies and every right no longer implied a correlative duty. Social order had been replaced — and ensured — by collective social practice and belief.

Human rights were not the only ideas proposed for governance-byconsciousness. There was also democracy, human freedom, and the human propensity to truck and barter. Neo-liberalism, after all, was not only the disciplining creed of a few international financial institutions and first world governments; it was the spirit of an age, enforcing itself wherever two were gathered in its name, in city governments, corporate boardrooms, local central banks and dozens of national civil services. In this, the Manhattan School echoed Wilhelm Roepke's famous description of the liberal order of the nineteenth century, held together not by institutions of global governance but by a common appreciation of the "liberal principle" that governments should simply not allow the political to contaminate the economic. For Roepke, this "liberal spirit," plus the Gold Standard, constituted what he termed an "As-If-

and National Policy: A Criterion for Judicial Abdication, 44 MinN. L. Rev. 1101 (1960); Thomas M. Franck International Law: Through National or International Courts?, 8 VILL. L. REV. 139 (1962-63); Thomas M. Franck, The Power of Legitimacy Among Nations (Oxford Univ. Press 1990); Thomas M. FRANCK, FAIRNESS IN INTERNATIONAL LAW AND INSTITUTIONS (Oxford Univ. Press 1995); Wolfgang Friedmann, Half a Century of International Law, 50 VA. L. ReV. 1333 (1964); WoLfGANG FriedMANN, The Changing STRUcture of InTERnATIONAL LaW (Columbia Univ. Press 1964); Wolfgang Friedmann, United States Policy and the Crisis of International Law, 59 AM. J. INT'L L. 857 (1965); Wolfgang Friedmann, The Relevance of International Law to the Processes of Economic and Social Development, 60 Proc. AM. SoC'Y OF INT'L L. 8 (1966); Wolfgang Friedmann, Law and Politics in the Vietnamese War: A Comment, 61 Am. J. INT'L L. 776 (1967); Wolfgang Friedmann, The Reality of International Law-A Reappraisal, 10 Colum. J. TRANSNAT'L L. 46 (1971); Louis Henkin, How NATIONS BeHAVE: LaW AND Foreign Policy (Praeger 1968); Louis Henkin, InTERnATIONAL LAW: Politics AND VAlues (Kluwer Academic Publishers 1995) (from Henkin's general course at the Hague Academy of International Law, 1989); Oscar Schachter, Dag Hammarskjold and the Relation of Law to Politics, 56 AM. J. INT'L L. 1 (1962), The Uses of Law in International Peace-Keeping, 50 VA. L. REV. 1096 (1964), Scientific Advances and International Law Making 55 CAL. L. REV. 423 (1967), Human Dignity as a Normative Concept, 77 AM. J. INT'L. L. 848 (1983), In Defence of International Rules on the Use of Force, 53 U. CHI. L. REV. 113 (1986). 
World-Government" more valuable and ethically compelling than the collectivist fantasies of both European and international lawyers after the Second World War. ${ }^{3}$ For the Manhattan school, it was the activist spirit of Dag Hammerskjold, working flexibly with great, if often contradictory, principles, along the boundaries of law and politics, East and West, guided by the imaginary perspective of an international community, an international judiciary, and an international jury of his peers.

The third great project of re-imagination was a bit of a reaction to the reaction. We might place it at Yale, in the person of Harold Koh, though I suspect he would trace his lineage to Philip Jessup, and it is probably more accurate to locate the origins at Harvard, home to the legal process tradition, to Det Vagts, Henry Steiner, Abe and Toni Chayes and Anne Marie Slaughter. ${ }^{4}$ For these thinkers, the key to global governance lay in national law, national courts and the procedures for allocating authority among them. The state was opened up, broken apart, replaced by the shifting internal dynamics of national bureaucracies and local powers, and the distribution among them of the authority to resolve various issues. The focus shifted from keeping the peace, structuring co-existence or facilitating projects of cooperation to dispute resolution and the chastening of political will which comes with exposure to the sands of international reaction. Their work was also interdisciplinary, drawing on public choice theories and new institutionalisms in both political science and economics.

No doubt these traditions overlapped and learned from one another. Each explicitly rejected conventional disciplinary boundary, blurred public and private, national and international, and drew inspiration from colleagues (1954).

3. See Wilhelm Röpke, Economic Order and International Law, 86 RECUEIL DES COURS 203

4. Abram Chayes et al., The International Legal Process (Little, Brown and Co., 1968); Abram Chayes, The Cuban Missile Crisis, (Oxford Univ. Press 1974); Abram ChaYes and ANTONia Handler Chayes, The New Sovereignty: Compliance with International Regulatory AgreEments (Harvard Univ. Press 1995); Harold H. Koh, Transnational Legal Process, 75 NeB. L. ReV. 181 (1996); Harold H. Koh, Commentary: Is International Law Really State Law?, 111 HARV. L. ReV. 1824 (1998); Harold H. Koh, The Globalization of Freedom, 26 YALE J. INT'L L. 305 (2001); Anne-Marie Burley, Toward an Age of Liberal Nations, 33 HARV. INT'L L. J. 393 (1992); Anne-Marie Slaughter-Burley, International Law and International Relations Theory: A Dual Agenda, 87 AM. J. INT'L L. 205 (1993); Anne-Marie Slaughter-Burley, International Law in a World of Liberal States, 6 EUR. J. INT'L L. 503 (1995); Anne-Marie Slaughter, Interdisciplinary Approaches to International Economic Law: Liberal International Relations Theory and International Economic Law, 10 AM. U. J. INT'L L. \& POL'Y 717 (1995); Anne-Marie Slaughter, The Accountability of Government Networks, 8 IND. J. GLOBAL LEG. STUD. 347 (2001); Henry J. STEINER ET AL., Transnational Legal Problems: Materials AND TeXT (4th ed. 1994); Detlev F. Vagts, The United States and Its Treaties: Observance and Breach, 95 AM. J. INT'L L. 313 (2001); Detlev F. Vagts, International Law in the Third Reich, 84 AM. J. INT'L L. 661 (1990); Detlev F. Vagts, The Traditional Legal Concept of Neutrality in a Changing Environment, 14 AM. U. INT'L L. REV. 83 (1998). 
elsewhere in the social sciences. For each, the legal order stood at the center of global order. For each, the global order had a structure - a world of cooperation and co-existence, of democracies and others, of states promoting a world public order of freedom or justice and those with more dubious designs. Each had something to say about the middle spaces of transnational cultural influences, families of law, public/private partnerships, soft power and social influence. Each rejected the pictures of law drawn by earlier schools of legal thought as they remembered them, whether "naturalism" or "positivism," "formalism" or "realism." And they rejected the images of law drawn by laymen and colleagues in other disciplines looking at the legal regime from the outside. From that perspective, the fluidity and pluralism of the legal system, the immanence of value in legal order, as well as law's engagement with social and political processes were all not visible. From the inside, it was all invention, imagination, new governance and the art of managing conflicting principles while aiming for the receding horizon of global justice.

There is now a large literature assessing the weaknesses and limitations of these schools of thought. They have criticized one another and survived long enough to give rise to internal eddies of discontent and rethinking. I won't revisit here what went wrong. Like the disciplines which preceded them, they remain all around us, their central ideas, institutional and doctrinal innovations remain useful, and are, in fact, used every day by courts, diplomats, activists and scholars.

Already when I began teaching international law, more than twenty years ago, it seemed sensible to look outside this lexicon for "new approaches to international law." For years we found ourselves fully occupied simply understanding the history and limits of these many earlier efforts to think in new ways about how the world is legally constituted. Just when we were beginning to think we might have had it licked, I am afraid that these traditions, like those which they overthrew, lost their ability to inspire. They remain active, paradigms for today's routine academic practices. But they suddenly seem parochial, studied elsewhere as yet more idiosyncratic emanations of the American empire. Each has been sullied by the struggle for policy bite in Washington. Moreover, I am sure their proponents would agree that even at their best, these more recent traditions remain rudimentary and partial answers to the question "how are we governed at the global level." Much remains to be learned.

The last few years have brought yet another group of large scale proposals to re-interpret the world of law. All stand on the legacy of our traditional disciplines, renewed by Yale, Manhattan and Harvard. Let me mention just a few, to give a sense for the scale and diversity of the efforts underway. 
Although I doubt they will ultimately be most influential, it is useful to begin with the many scholars who have experimented over the last few years with the metaphor of a "constitution" to describe the legal order beyond the nation state. ${ }^{5}$ Many in European legal circles were entranced by the idea that their new bureaucratic machinery might be re-christened a constitutional order. In public international law, we have been encouraged to think of the U.N. Charter as a "constitution," particularly when it comes to the use of force. Others have seen a "constitutional moment" in the emergence of human rights as a global vernacular for the legitimacy of power. Some trade scholars have proposed that we see the World Trade Organization ("WTO") as a constitutional order. The WTO has rendered the GATT more properly legal, strengthening dispute settlement and deepening engagement with national legal regulations. If, as Ernst-Ulrich Petersmann urges, we were to add human rights to what John Jackson famously termed the WTO's substantive legal "interface" between national regulatory systems, we might well see the result as a constitution, at least to the extent we are willing to see the legal regime of the European Union in constitutional terms. At the same time, others find the key to world public law in the relations among national constitutions. Comparative constitutional law is front and center in their accounts of how we are governed at the global level.

These efforts are interesting because they illustrate most starkly both the wish that things were, in fact, legally constituted in some way and the realization that we do not now have a workable description of the world's legal order. The constitution must be written, discovered-our various partial institutions reinterpreted in constitutional terms.

I expect those most enthusiastic about constitutional metaphors understand all too well that theirs is not only a proposal to discover the world's constitution, but a project to interpret the world as constituted, held together in constitutional terms. Wouldn't things be better if the world's legal order were constituted, whether by the WTO or the UN Charter or in some other way? And we know that in such matters saying it can sometimes make it so. This is why the effort to imagine a world constitution can sometimes feel so morally and politically urgent. If you think constitutionalism has

5. See for example Bardo Fassbender, The United Nations Charter As Constitution of The International Community, 36 COLUM. J. TRANSNAT'L L. 530 (1998) which discusses the notion of the UN Charter as a global constitution noting similar ideas in ALFRED VERDROSS \& BRUNO SIMMA, UNIVERSELLES VÖLKERRECHT: THEORIE Und PRAXIS (3d ed. 1984). See also Anne-Marie Slaughter and William BurkeWhite, An International Constitutional Moment, 43 HARV. INT'L L.J. 1 (2002); John O. McGinnis and Mark L. Movsesian, Commentary: The World Trade Constitution, 114 HARV. L. REV. 512 (2000); ErnstUltrich Petersmann, Trade Policy as a Constitutional Problem: On the Domestic Policy Functions of International Rules, 41 AUSSENWIRTSCHAFT (1996): Ernst-Ultrich Petersmann, The WTO Constitution and Human Rights, 3 JOURNAL OF INT'L ECON. L. 19 (2000). 
worked well at home and that your own constitution may even be threatened by global pressures of one sort or another, it can feel like a project of the utmost seriousness and urgency to interpret the world in constitutional terms.

But constitutionalist re-description is but one of many ongoing efforts to rethink the legal order by which we are governed globally.

We might start with the enormous project of legal sociology underway at Australian National University to map the world of "regulation." Peter Drahos and John Braithwaite begin with the observation that an enormous number of rules are neither made nor enforced by states and those which are will often have been written and may well be enforced by people in other states and other institutions. ${ }^{6}$ They focus on private ordering, standard setting bodies, the social practices and patterns of influence within industry and professional bodies. Their project is descriptive-who functions in this hidden world where rules are made, how do they become powerful, what kinds of rules and principles travel from one domain to another and which are left behind? Their ambition is to share knowledge and access to the inner workings of global regulation more equitably and to empower those left out of the process.

Then there is the new project on "global administrative law" at New York University. ${ }^{7}$ Richard Steward, Ben Kingsbury and their colleagues seek to rethink public power as a form of administration, regardless of whether it is exercised by courts or private actors, integrated into a conventional hierarchy of public authority or dispersed across the globe. Looked at this way, they ask whether conventional administrative law reforms - transparency, participation, opportunity to be heard, judicial review - might not offer a recipe for improving global governance.

At the same time, in Frankfurt, we have the work of Gunther Teubner and others influenced by Niklas Luhmann's "systems theory." Perhaps, they

6. John Braithwaite and Peter Drahos, Global Business Regulation (Cambridge Univ. Press 2000). The project of which this work is a part (the Regulatory Institutions Network or "RegNet") has spawned a truly voluminous interdisciplinary literature over the past eight or so years that spans a diversity of topics. RegNet's past publications are detailed at http://regnet.anu.edu.au/program/ publications/index.php.

7. See Benedict Kingsbury, Nico Krisch \& Richard Stewart, The Emergence of Global Administrative Law, 68 L. \& CONTEMP. PROBS. 15 (2005); Benedict Kingsbury, The Administrative Law Frontier in Global Governance, 99 PROC. AM. SOC'Y OF INT'L L. (2005). See also Benedict Kingsbury and Nico Krisch (special eds.) Symposium on Global Governance and Global Administrative Law in the International Legal Order, 17 EUR. J. INT'L. L. 1 (2006). For further bibliographical resources for the global administrative law literature, see $A$ Global Administrative Law Bibliography, 68 L. \& CONTEMP. PROBS. 357 (2005) and http://www.iilj.org/GAL/documents/GALBibliographyMDeBellisJune2006.pdf.

8. Gunter Teubner and Andreas Fischer-Lescano, Regime-Collisions: The Vain Search for Legal Unity in the Fragmentation of Global Law, 25 MiCH. J. INT'L L. 999 (2004); GUNTHER TEUBNER, LAW AS AN AutOPOIETIC System (Blackwell 1993); Gunther Teubner, The King's Many Bodies: The Self- 
argue, the world is ordered in a series of semi-autonomous systems, loosely associated with industries or domain of social practice or belief, each with its own rules and procedures, even constitutional procedures and principles, pursuing its own logic: a health system, a sports system, a trade system, a pharmaceutical system, and so on. Governments, or certainly diplomacy, would be but one system among many. The research objective is to identify these systems, study their emergence and interaction, in search of a general model - what constitutes a system, how do they change and interact with one another, how are conflicts resolved, how are systems defended?

We also have an emergent body of literature proposing "new governance" ideas developed domestically and in Brussels for the international order. Embracing tenets of "democratic experimentalism" and innovative institutional arrangements disconnected from more traditional modes of thinking about law and regulation, scholars of this school seek to wed notions of democratic legitimacy with economic efficiency in an ambitious project of renewal and change. ${ }^{9}$

One of the most interesting and sustained grand projects of reimagination has been the effort by a new generation to rethink the relationship between the international law and the Third World. Sparked by the work of scholars like Tony Anghie, Makau Mutua, James Gathii, B.S. Chimni and Balakrishnan Rajagopal, this intellectual movement is not associated with a universityparticipants have found footholds here and there, and only in London, at

Deconstruction of Law's Hierarchy 31 L. \& Soc. Rev. 763 (1997); Gunther Teubner, Contracting Worlds: The Many Autonomies of Private Law, 9 Soc. \& LEG. STUD. 399 (2000). See also the collected essays in Global LAW Without a STATE (Guther Teubner, ed., 1997). This literature draws strongly on Niklas Luhmann's "system theory" approach. See broadly NiKLaS LuHMANn, SOCIAL SyStEMS (John Bednarz \& Dirk Baeker trans., Stanford Univ. Press, 1995); Niklas LuhMANN, LAW AS A Social SySTEM (Fatima Kastner et al. eds., Klaus A. Ziegert trans., Oxford Univ. Press 2004).

9. See, for example Charles F. Sabel, A Quiet Revolution of Democratic Governance: Towards Democratic Experimentalism, in GovernanCE IN THE 21st CENTURY 121 (OECD 2001); Michael Dorf \& Charles F. Sabel, A Constitution of Democratic Experimentalism, 98 Colum. L. Rev. 267 (1998); Charles F. Sabel and William Simon, Destabilization Rights: How Public Law Litigation Succeeds, 117 HARV. L. REV. 1015 (2004); James Liebman and Charles F. Sabel, A Public Laboratory Dewey Barely Imagined: The Emerging Model of School Governance and Legal Reform (2003) 28 N.Y.U. REV. OF L. AND Soc. ChANGe 183; Gráinne de Búrca, The Constitutional Challenge of New Governance in the European Union, 28 E.L.R. 814 (2003); LAW AND NEW GOVERNANCE IN THE EU AND THE US (Gráinne de Búrca and Joanne Scott eds., Hart Publishing 2006); Susan Strum, Second Generation Employment Discrimination: A Structural Approach, 101 ColuM. L. ReV. 458 (2001); David M. Trubek and Louise G. Trubek, Hard and Soft Law in the Construction of Social Europe: the Role of the Open Method of Coordination, 11 EuR. L. J. 343 (2005). See also Orly Lobel, The Renew Deal: The Fall of Regulation and the Rise of Governance in Contemporary Legal Thought, 89 MINN. L. REV. 342 (2004), which provides a good overview of a large portion of the new governance literature. For some of my thoughts concerning the new governance approach, see David Kennedy, Remarks for the "New Governance Workshop" Harvard Law School, February 25-26, 2005, available at http://www.law.harvard.edu/faculty/dkennedy/speeches/ Remarks.pdf. 
SOAS and the affiliated schools of the University of London do you find a critical mass. ${ }^{10}$ They are exploring the continuing significance of the colonial project for the structure of global law and political life, identifying issues not solved by transforming the dominions into formal sovereigns that they might participate in the institutions of intergovernmental life and take responsibility for territorial government. As one might expect from the work of a broad network, the results are far more diverse in viewpoint and method than what has so far emerged from the parallel efforts at NYU or ANU or Frankfurt. What they share is the ambition to redraw the map of global governance from the periphery, placing altogether different issues and modes of rulership in foreground focus and dissatisfaction with their own intellectual forefathers in the era of decolonization every bit as intense as that felt by the reinventions of the North about our conventional disciplines.

These are all powerful reconceptualizations. It is always tempting in this sort of situation to imagine that each has hold of one piece of the elephant. They do, certainly. But they are also each proposing a different elephant. Each offers a vision, more or less in the mode of our conventional disciplines before them, which they claim to be a more complete account, a plausible total

10. For current scholarship associated with Third World Approaches to International Law, see: Anthony Anghie, Francisco de Vitoria and the Colonial Origins of International Law, 5 Soc. \& LEG. Stud. 321 (1996), Finding the Peripheries: Sovereignty and Colonialism in Nineteenth Century International Law, 40 HARV. INT'L L. J. 1 (1999); Anthony Anghie, Colonialism and the Birth of International Institutions: Sovereignty, Economy and the Mandate System of the League of Nations, 34 N.Y.U. J. INT'L L. \& POL. 513 (2002); ANTHONY ANGHIE, IMPERIALISM, SOVEREIGNTY AND THE MAKING of International Law (Cambridge Univ. Press 2005); Upendra Baxi, The "War On Terror" And "The War Of Terror": Nomadic Attitudes, Aggressive Incumbents And The 'New' International Law; Prefatory Remarks On Two Wars, 43 OsGOOdE HALL L. J. 7 (2005); Bhupinder Chimni, International Institutions Today: An Imperial Global State in the Making 15 E.J.I.L.1 (2004); James Gathii, International Law and Eurocentricity, 9 E.J.I.L. 184 (1998); James Gathii, Alternative and Critical: The Contribution of Research and Scholarship on Developing Countries to International Legal Theory, 41 HARV. INT'L L. J., 263 (2000); James Gathii Neoliberalism, Colonialism and International Governance: Decentering the International Law of Governmental Legitimacy, 98 MicH. L. REV. 1996 (2000); Balakrishnan Rajagopal, Locating the Third World in Cultural Geography, 1998-9 THIRD WORLD LEG. STUD. 1 (1999); BALAKRISHNAN Rajagopal, INTERNATIONAL LaW From Below; DeVElopMEnt, SOCIAL MOVEMENTS AND THIRD WORLD ReSISTANCE(Cambridge Univ. Press 2003); Makau Mutua, What is TWAIL?, 94 Proc. Am. SoC'Y OF INT'L L. 31 (2000); Makau Mutua, Critical Race Theory and International Law: The View of an InsiderOutsider, 45 VILL. L. ReV. 841 (2000); Makau Mutua, Savages, Victims, and Saviors: the Metaphor of Human Rights, 42 HARV. INT'L L. J. 201 (2001); Karin Mickelson, Rhetoric and Rage: Third World Voices in International Legal Discourse, 16 WISC. INT'L L. J. 353 (1997); Obiora Chinedu Okafor, Newness, Imperialism, and International Legal Reform in our Time: A Twail Perspective, 43 OSGOOdE HALL L. J. 171 (2005); Obiora Chinedu Okafor, The Third World, International Law and the Post 9/11Era: An Introduction, 43 Osgoode HaLl L. J. 1 (2005); Amr A. Shalakany, Arbitration and the Third World: A Plea for Reassessing Bias Under the Specter of Neoliberalism, 41 HARV. INT'L L. J. 419 (2000). See also Symposium: Globalization at the Margins: Perspectives on Globalization from Developing States, 7 IND. J. OF GLOBAL L. StUd. (1999). 
or ground level answer to the question of how we are governed, as a candidate to function as queen of the sciences when it comes to global governance. We ought not to dismiss these claims as misguided hubris. Constitutionalism, of course, has claimed pride of place for years in our own legal academy, as the study of process, civil procedure and federal courts did a generation before, or private law before that. The structure of governance has always been both the sum of the disciplinary insights spawned in its name and a struggle among perspectives claiming to be foundational.

If we are to embrace constitutionalism, we will need to explain not only what it adds to the knowledge we have gleaned from, say, public international law or international economic law, but what it means to treat constitutionalism as, well, constitutional. Each field, after all, carries with it a disciplinary sensibility about what the problems are and where solutions lie. Standing on each foundation, some problems will be easy to see, others harder. Some actors and authorities and perspectives will be foregrounded, others not. As we compare frameworks for thinking about global governance, we will need to assess their relative blindness and insight and the consequences of treating one rather than another as the base. What projects of reform, what space for politics, will be enabled setting off from one rather than another of these various points of view?

Moreover, these are certainly not the only new ideas out there about how it all fits together. The traditions of public choice and institutional economics, imported into law by law and economics scholars, also propose new ways of explaining global legal order. ${ }^{11}$ I have mentioned only projects well known

11. William J. Aceves, The Economic Analysis of International Law: Transaction Cost Economics and the Concept of State Practice, 17 U. PA. J. INT'L ECON. L. 995 (1996); DOUgLaS G. BAIRD ET AL., Game Theory and the LAw (Harvard Univ. Press 1994); Eyal Benvenisti, Collective Action in the Utilization of Shared Freshwater: The Challenges of International Water Resources Law, 90 AM. J. INT'L L. 384 (1996); Robert D. Cooter, Structural Adjudication and the New Law Merchant: A Model of Decentralized Law, 14 INT'L REV. L. \& ECON. 215 (1994); Jeffery Dunoff and Joel Trachtman, Economic Analysis of International Law, 24 YALE J. OF INT'L L. 1 (1999); Jack L. Goldsmith and Eric A. Posner, A Theory of Customary International Law, 66 U. CHI. L. REV. 1113 (1999); Moshe Hirsch, The Future Negotiations over Jerusalem, Strategical Factors and Game Theory, 45 CATH. U. L. REV. 699 (1996); Jonathan R. Macey, Chicken Wars as a Prisoner's Dilemma: What's in a Game? 64 NOTRE DAME L. REV. 447 (1989); William B.T. Mock, Game Theory, Signaling, and International Legal Relations, 26 GeO. WASH. J. INT'L L. \& ECON. 33 (1992); Joel R. Paul, The New Movements in International Economic Law, 10 AM. U. J. InT'L L. \& POL'Y, 607 (1995); Paul B. Stephan, Barbarians Inside the Gate: Public Choice Theory and International Economic Law, 10 AM U. J. INT'L L. \& PoL'Y 745 (1995); Paul B. Stephan, Accountability and International Lawmaking: Rules, Rents, and Legitimacy, 17 NW. J. INT'L L. \& BUS. 681 (1996-97); Alan O. Sykes, Protectionism as a Safeguard: A Positive Analysis of the GATT "Escape Clause" With Normative Speculations, 58 U. CHI. L. REv. 255 (1991); Alan O. Sykes, The Economics of Injury in Antidumping and Countervailing Duty Cases, 16 INT'L REV. L. \& ECON. 5 (1996); Joel P. Trachtman, The Theory of the Firm and the Theory of the International Economic Organization: Toward Comparative Institutional Analysis, 17 Nw. J. INTL L. \& BuS. 470 (1996-97). 
in the English language academy. But we must imagine there is rethinking underway as well in Moscow and Tehran and Beijing and-it will be a long list. And we are still looking only at the projects in law - there are every bit as energetic projects moving ahead across the social sciences.

Having multiplied things so far, I should probably come clean as having my own pet project of totalizing re-description. My own focus has been on the work of experts and the significance of expert knowledge in governing our world. Over the last several years, I have studied the work of various experts -international lawyers, human rights activists, military professionals, experts in economic development - to understand the nature of their expertise, the knowledge they bring to bear, their background consciousness about what is and is not part of their domain, the terms through which they argue for one or another position, and the channels through which they make what they know real. On the basis of these preliminary studies, I have proposed pieces of what I hope will become a general model of expertise and the work of experts in global governance. ${ }^{12}$

For now, let me simply say that I have become convinced the role of experts is drastically understudied. We focus on statesmen and public opinion and not enough on the ways in which their choices, their beliefs, are shaped by background players. After all, if for a generation everyone thinks an economy is a national input/output system to be managed, and then suddenly they all become convinced that an economy is a global market for the allocation of resources to their most productive use through the efficiency of exchange in the shadow of a price system, lots has changed. That is also governance. At the same time, our ideas about experts and expertise are rarely realistic. We often overestimate their capacity and influence. We imagine that development economists know how to bring about development or that lawyers know how to build an institution or draft a statute to bring about a desired result. What holds them back is the friction and resistance of context - or incompetence. At the same time, we rarely have a good picture of the blind spots and biases introduced by expertise, along the lines of the old adage that to a man with a hammer, everything looks like a nail. Indeed, experts

12. See for example David Kennedy, Challenging Expert Rule: The Politics of Global Governance, 27 Sydney. L. ReV. 5 (2005); David Kennedy, The Dark Sides of Virtue: Reassessing InTERNATIONAL HumanitaRianism (Princeton Univ. Press 2004); DAVID KeNNEDY, OF WAR AND LAW (Princeton Univ. Press 2006); David Kennedy, The Politics and Methods of Comparative Law in THE Common Core of European Private LaW: EsSays on the Project 345 (Mauro Bussani and Ugo Mattei eds., Kluwer Law International 2003); David Kennedy, New Approaches to Comparative Law: Comparativism and International Governance, 1997 UTAH L. REV. 545 (1997); David Kennedy, Laws and Developments in LAW AND DEVELOPMENT:FACING COMPLEXITY IN THE 21 ST CENTURY 17 (Amanda PerryKessaris and John Hatchard eds., Cavendish Publishing 2003); David Kennedy, The International Style in Postwar Law and Policy, 1994 UTAH L. R. 7 (1994). 
rarely know what they don't know and know a great deal that is fashion, that is borrowed, misunderstood, reduced to a slogan, or simply too contradictory to be "applied" or "implemented" straightforwardly.

It may be unwise to call what I am after "experts" and "expertise," for we are used to equating these terms with the work of the professions - scientists, technical people, doctors and lawyers. My hypothesis is broader: that the relationships between power and knowledge which we can see in the professions most familiar to us - international lawyers, development professionals - may well model the relationship between what both laymen and leaders know and do. Politicians are also experts, of a sort, as are citizens. It is not just that they have learned to think about international affairs from expert talking heads. It is that they also play roles and learn about their commitments and possibilities in social networks akin to disciplines or fields.

For all these people - technical experts, politicians, citizens - it is not at all obvious how ideas become policies or how the expertises of various fields or disciplines blend together in that process. But I am convinced that were we to understand the mutually constitutive relationship between professional practice and knowledge we would have displaced the agent/structure debate which has paralyzed so much of the social sciences when thinking about international affairs. Rather than agents in structures, we might come to see people with projects, projects of affiliation and disaffiliation, commitment and aversion, and with wills to power and to submission. We would find these people organized in disciplines, speaking with one another in the vernacular perhaps of public international law or international economic law or constitutionalism. Their disciplines would have a history, an intellectual history, and an institutional and political history. Their knowledge would be less recipe than rhetoric. Their practice would often be best understood as assertion and argument, the vernacular of those arguments structured like any other language. Were we to pursue this approach, we would focus less on procedures or institutions, or even substantive norms and values. The constitution, if we could call it that, for global governance would be written in the disciplinary habits, including the habits of mind and patterns of argument, of people with projects operating with expertise.

\section{Comparative Evaluation: Things We Should Be Sure to SeE}

Against this background, I come to the mystery of global governance in a skeptical and comparative frame of mind. The range of proposals for understanding the structure of our legal world makes me skeptical that we will find any of these tales persuasive. Useful, perhaps, but can it really be that we are so soon constituted? Do we know enough about the structure of global arrangements, whether legal or political, economic, cultural, to be confident that what we know domestically as "constitutionalism" is a good idea for the 
globe? What if the distances are so great, the forces so chaotic, the differences in situation so profound that the constitution ratifies what ought rather to be transformed?

At the same time, these are the proposals on the table: constitutionalism, global administrative law, autopoetic regulatory systems, and so on. How ought we to compare them? Each has given rise to a specialized profession. Each offers a focal point for reform. In comparing their vices and virtues, we will each have our own list of issues and facts about the world we think it particularly critical to take into account and we will each judge these various efforts in part by their ability to do justice to our own preoccupations. Let me share a few of my own,- the check list against which I would judge the constitutionalist, or any other, project to rethink global governance. A brief list of things to which I worry we have paid insufficient attention.

First would be the sheer density of rules and institutions in the global space. We often imagine that the world is an anarchic struggle or a deregulated market over which we have managed to throw but a thin net of rules. But the situation is more the opposite - law and regulation and rule at every turn. Economic globalization means legal globalization; every crate travels with a packet of rights and privileges, every transfer relies on a network of institutions and rules. The internationalization of politics means the legalization of politics. Every agent of the state, of the city, of the region, acts and interacts on the basis of delegated powers, through the instruments of decision and rule and judgment. Indeed, globalization has fragmented both economic and political power, but it has not de-legalized it. On the contrary, even war today - asymmetric war, high-tech war, war stretched across a global battlespace, war of missiles and missives - is an affair of rules and regulations and legal principles. As a result, the problem is not to bring political or legal actors into law, but to understand and, where necessary, rearrange the laws which constitute those actors, channel their interactions and influence their relative powers.

Second, and related, is the disorderliness, the pluralism, the uncertainty, the chaos, of all those rules and principles and institutions. The globalization of law, the legalization of politics and economics, has brought with it a tremendous dispersion of law. All manner of rules, enforced and un-enforced, may, as a matter of fact, affect any global transaction. And as a matter of law - conflicting and multiplying jurisdictions, asserting the validity or persuasiveness of their rules, with no decider of last resort. Some of this disorder is structured in one or another way - various federalisms, multiple jurisdictions, choices of law provisions, even races to the top and bottom. But some is also a matter of struggle and conflict, between legal orders, ideas, powers and traditions. Our picture will need to have room for all this disorder - there is no use denying or overlooking it, pretending coherence. And it is not at all clear the situation would be improved by a net reduction in the 
plurality of law - it might or it might not. Some would gain and others would lose. We will need to assess the dynamic and distribution effects of one or another attitude toward the disorderliness of global governance.

Third are a series of issues we might think of as the inverse side of law. I worry that our ideas about global governance pay too little attention to the informal and the clandestine - to customary norms, background patterns of private and public expectation, black markets and illegal flows. We rarely distinguish carefully the many degrees of separation from the legal foreground - the clandestine, the informal, the illegal, the corrupt, the black marketmay all be quite different. Moreover, as everyone exercising a prosecutor's discretion to bring charges well knows, those who govern often strategize about residual of non-compliance to be tolerated. Under a regime of exchange controls, a black market may be more effective than a tariff, and so on. We will need to pay more attention to these back-side calculations and effects, and articulate more clearly how awareness of their significance alters our sense for the big questions: where and what is global power, how is politics organized, where are the levers for change?

In a similar vein, we are prone to imagine that things which happen in the exceptions to rules as outside the law altogether. As if the exception was not also a rule. Guantanamo, for example, far from being a legal black hole, is one of the most regulated places on the planet; it is simply that different rules apply and different rules do not apply. Indeed, our pictures of global governance are woefully inadequate in their attention to the significance of legal privileges. We forget that law is not merely a matter of rights and duties, but also of privileges to injure without compensation. When UNHCR knocks on the door of a sovereign and asks that a refugee be admitted, the response will be rooted not only in sovereign power but also in legal privilege - the privilege to exclude, to define those one will admit, to defend and fence the national territory. Despoiling the rainforest is not only an economic decision; it is also the exercise of legal privilege. In our thinking about global governance, I worry that we focus too much on the fate of a few hundred detainees held here and there, while our legal order meanwhile wraps the violent wartime deaths of thousands in the "privilege" to kill on the battlefield and the comforting reassurance that all the "collateral damage" was proportional, necessary, and reasonable. It is customary to understand things we don't like - war or poverty or sovereign discretion - as facts or powers prior to law. But each is also a legal institution. A refugee is not simply a person who flees his homeland; a refugee is also a legal status and legal regime which governs those who flee, often radically transforming who may leave, where they may go, and even whom they will imagine themselves to be.

I suppose it is not surprising that when we pick up a book about international law to find out how the environment is regulated, we turn to the chapter labeled "international environmental law." What we would find are 
the most prominent international rules and principles and institutions dedicated to environmental protection. But we know the law also offers comfort to the despoiler, to the sovereign and company and property owner who wants to cut down that forest, just as we know that the legal regime for migration is far broader than rules about citizenship and asylum. Migration is also a function of employment law and social security and family law and taxation and banking and criminal law and ... it is hard to see the edge. It we sought a comprehensive guide to the laws affecting the incidence of interstate violence we would probably not even begin with the laws of war. Much would depend on our theory of violence; if it is all about economic struggle, we would look to the laws constituting economic power and distributing access to resources. If war was but another method of dispute resolution and diplomatic communication, we would look at the law structuring the diplomatic process, claims, state responsibility, countermeasures and the rest. And so on.

Fourth, as I have said, it is easy to think about global governance, particularly when thinking about it constitutionally, as a static plan, a machine to be turned on. But our various proposals and reinterpretations will fall into an ongoing and unruly process. They will strengthen forces and weaken others in ways which will change how they function. Global governance is already underway and proposals for its improvement will need to think strategically about the forces which must be strengthened to ensure their success. Are we betting on the middle powers, on the great democracies, on those with capacity to project force abroad, on the rising giants of India and China, South Africa or Brazil?

There is nothing unusual in the idea that a scheme for global governance ought to be conscious not only about who will win and lose, but about whom one expects to carry the program to victory. For the United Nations, it was to be the United States, founder, host and leading source of funds, along with the other Allied Powers granted veto status in the Security Council. Powers changed, new players emerged, and the Charter was amended, in practice if not in text. It is also easy to see that the success of the GATT depended upon harnessing the great trade blocs and dominant traders within its terms from the start, just as the Coal and Steel Community, whatever its legal structure, depended upon cementing a core trade-off between France and Germany which could be expanded, both geographically and substantively. The interests to be engaged were not simply states; they were farmers and industrialists. Indeed, trade scholars have long understood that bargaining in the GATT or WTO — running a successful "trade war" if you like-is all about placing pressure on domestic social and economic sectors one suspects may be able to move public decision-makers abroad: perhaps farmers or cheese-makers or the automotive industry. The WTO offers a framework for gaming conflicts among interests internal to other states. 
Of course, not all contemporary discussions of global governance are silent on their implicit political and economic strategy. But I must say I worry about the plausibility of the coalitions many of today's most popular governance projects would place on the field to ensure their coming into being - non-governmental actors, national judges, international media elites, foundations, corporations enacting new found ideas about social responsibility, wrapped together and styled the "international community" or "international civil society." There is certainly power there. But it can also be a rather weak reed, can stimulate a backlash more powerful than what it can bring to the table in defense, and can lash a global governance system to a narrow vision of the interests and issues to be managed. It is easy to overlook conflict and risk and alternative visions of society and justice when your constituents have styled you as the voice of the universal.

In a similar vein, I worry that our efforts to comprehend global governance have focused far too much on the authority of agents we can see to act within structures we understand. We have paid too little attention to the myriad ways power flows through the capillaries of social life, perhaps particularly at the global level. Many of these are flows of finances, of resources, of arms. But many are flows of belief, modes of knowledge, of affiliation and disaffiliation, the social movement of wills to power, the desire to submit, the experience of triumph and victimization, pride and shame. All these things move like a virus or a fad, but our epidemiology is weak, our sociology of status, convention and emulation at the global level rudimentary.

In a sense, governance by knowledge is easy to picture. We know that the idea of a "national economy" or a "nation-state" can rise and fall, changing a great deal about how people govern and how they imagine themselves in community. Similarly, by tracing the rise and fall of endogeneity in economics, we might learn a great deal about what seems possible for policy in different places and times. But imagine a map of global governance which tracked the distribution of pride and shame across the world's economies, political configurations, social and cultural forms. I am convinced we would find that social power and submission and all the pleasures and rages which accompany them both on the global stage will also turn out to be matters of governance and law.

Fifth, and finally, I worry that our projects to rethink global governance fail to grasp the depth of the injustice of the world today and the urgency of change. They are projects of moderate reform for which the normal is stable and sustainable. Even our best disciplinary maps make inequality and domination in the world system difficult to see. We imagine that poverty was and remains simply there, precursor to growth, fact and context for policy. We understand far too little about the dynamic relationship between growth and poverty. In a similar way, the relationship between rulership and exclusion remains as difficult to understand as that between global governance 
and the informal world of clandestine flows. The alchemy by which inequality becomes routinized through the vernacular of experts and hardens as law is tough to unravel, but the effects are everywhere on view. Just writing the history of domination and inequality, and their erasure, into the maps legal intellectuals have already produced will be a great work.

We will each come to debates about global governance with a sense for the challenges we face. The sustainability of our lifestyle and our environment surely makes the list. Then there is the demographic challenge, so pronounced in Europe and the ex-Soviet Union, but also here, or in Saudi Arabia, which will force a reckoning with immigration or security or both. There is the challenge posed by economic success in the third world, by the hundreds of millions of Chinese and Indian individuals who have emerged from poverty into our industrial present. Speaking loosely, and to put it in the starkest terms, with economic globalization and the continued loss of public capacity, large swaths of the world will, in twenty years, have whatever social security system, whatever environmental regime, whatever labor law, whatever wage rate prevails in China.

And there is the parallel challenge posed by economic failure in the third world, by the revolution of rising frustrations among the hundred of millions of individuals who can see in, but for whom there seems no route through the screen except through rebellion and spectacle. If you put just these threats together, we confront an accelerating social and economic dualism-a rumbling fault line between two global architectures, between an insider and an outsider class, between leading and lagging sectors, both within and between national economies and political units.

It is disheartening that while the world fractures, so many of our debates about global governance are content merely to embroider the habits of the technical class, decorating their management with intellectual filigree. So much scholarship today is simply a brief for the significance and vitality of a narrow professional culture and sensibility. Its authors struggle for political rapprochement between a center-right attuned to market failures and a centerleft that has lost faith in its own nostalgia for what it remembers as the potent regulatory and administrative state of earlier days. These political tendencies are status quo parties, timid about social conflict, hesitant about distribution, resigned to poverty, harnessed to a culture of warfare.

I would prefer we set out with questions of political economy in the foreground and that we came to global governance and the constitutionalization of the planet not as an opportunity to depoliticize world affairs, but as the chance to pursue a new politics attuned to these challenges. How does the world remain so unequal, how is hierarchy and domination reproduced? What does law have to do with the organization of politics and economics? If you are an intellectual in the periphery of the world system - the intellectual, geographic, political, cultural or economic periphery-what can you do to 
change things? Our work on global governance should aim to answer questions like these.

We know, for example, that bargaining power is also distributed by law both between nations and across production chains. If the trading system is to be our world constitution, how does it distribute bargaining power in global markets? When small or medium sized enterprises in Vietnam compete with producers in Laos or Mexico and then bargain with globally networked purchasers - how does law allocate their powers? Who captures the rent? Not only developing governments and their employees seek rents; so do WalMart and Toyota and Chevron. Moreover, how are regulatory powers allocated where economic factors other than labor move more freely than sovereign power? Why do property rights travel so securely when the extraterritorial reach of labor law or employment discrimination or environmental protection law continues to seem unreasonable? How do we decide whether a low wage development strategy is an unfair subsidy or the extraterritorial application of labor law a non-tariff barrier to trade? Indeed, it may well turn out that antitrust or contract is the new global constitutional law. Should we so conclude, we will want to understand the industrial policy embedded within it.

In short, I worry that everywhere global public capacity is not only too anemic or irregular to confront the stakes of global poverty, conflict, injustice. It is also the instrument of that poverty, those conflicts, and that injustice. As a result, where our shared dreams about global governance remain rooted in the status quo, they risk lulling us into complacency. We need to remember, as we speak about these things, that all of us in the professional classes of the North confront the rest of humanity with our entitlements and lifestyle and also with our talk about the "international community" and "global governance." It is not enough any more to say we favor better law or good governance. We will need to ask for whom we govern, for what form of political, social and economic life do we propose a constitution.

\section{CONSTITUTIONALiSM AS Global GOVERnANCE}

Among the lawyers rethinking the way the world is ruled, the constitutionalists have an advantage. They put their wish for a coherent legal map of powers front and center. As a result, the limits are also on view: most crucially, the tendency of the constitutionalist vernacular to dress up normative projects in sociological terms. There is no question we need better maps of the legal regime through which we are governed globally. If we could understand how the whole scheme was constituted, we would be ahead of the game. But the current crop of constitutionalist images of global governance end up sounding far more like proposals to remake the world's 
political order by sacralizing the institutional forms with which they are most familiar. In this, they remind us to be wary.

It may be my background in American law, but I have always felt constitutionalism a rather weak sociology of the way power functions. The U.S. Constitution is fascinating as a meditation on the possible relationships among a series of legal authorities. As a text, it could be the stuff of normative imagination or political philosophy. I am sure it is sometimes a useful textual reference for interpretive practice in quite specific institutional settings. But it is a lousy description of power in American society, and a quite inaccurate map of how Washington works. Private power and economic form is altogether missing from the story, along with the role of political parties and money, the dynamics of social dualism in American life, changing ethical and political fashion, the world of background norms, informal and customary arrangements and much more. The document reads as if powers outside the territory and entities outside the text are irrelevant to public order. If we imagine the world it constitutes as our political world, we will miss a great deal

Perhaps our fledgling international constitutionalisms have it more to right, but I am worried by the extent to which people come to these debates carrying baggage from their national constitutional traditions. Most scholars of global governance think their own societies do work rather well and many credit their constitution in some way. Even if this is all true, we would still be right to question whether these constitutionalist ideas are useful at the global level, mostly for the familiar reason that international society is altogether different: larger, more fragmented, lacking, as they say, in demos. Take judicial review; it seems central, though many democratic constitutional traditions do not have it. As American lawyers, we are familiar with dozens of arguments about the uses and abuses of judicial review, all of which are expressed in very general terms - treating things like "executive power" and "independent judgment" as if they were universals we might place in an ideal relationship with one another rather than idealized descriptions of quite specific institutions in the particular context of American history and political life. Indeed, I have often thought it would be a useful heuristic in discussions of global governance here in the United States simply to ban the use of catch phrases and code words from American constitutional debates precisely so that we could better remember when we are speaking about general things and when about our own experience.

Moreover, I wonder whether our national constitution has done such a good job constituting us as a nation, or whether the American cult of the constitution has not also made us less able to see enduring divisions within our society or imagine links with people outside the territorial boundaries of the place we call the "United States." As a tool for social justice, we would have to concede the record is rather mixed. There have been some astonishing 
successes and important, if more routine pressure against governmental overreaching. But a great deal of injustice which has been routinized or legitimated. The inequality in education for citizens in side by side suburbs, one wealthy, the other poor, remains a scandal and it is rooted in legal arrangements and ideas about cities and property and taxation. Or take the Senate-by entrenching the power of the least populated states, the constitution has continuously structured the nation's political economy. Constitutions are about focusing political attention, removing some things from routine political struggle, placing others front and center, arranging the powers to be taken lightly and those to be accorded great respect.

On balance, we might be quite satisfied with how that has gone here at home. Our European colleagues might well feel the same way, if for different reasons and with a different history. But imagine a person who came to the constitutional discussion at the global level from a country with a different history of constitutionalism at home - a country whose constitution removed different issues from contestation, or where the constitution was irrelevant to the political struggles of the nation, or enshrined ethnic or religious divisions or political ideological commitments with which he or she disagreed, or whose formal terms had been altogether swamped by other modes of power sharing, rent-seeking or corruption. It is not just that such a person might not understand or value the global constitution we proposed, for we would certainly offer the world our own more workable arrangements. It might be that, as the global struggle among us unfolds, we will find ourselves with a global constitution of a completely different kind than we might anticipate around this table.

As a tool for thinking about global governance, the constitutionalist literature has some unfortunate biases. Perhaps most serious is the idea that the world is, in fact, "constituted," that things do add up, one way or the other. We might think of this as a bias against the perception of disorder or contradiction. There is often what we might call a "purposive bias," that elements in a constitutional order have a function, they are things you can do something with, they reflect social needs or have their justification one or another way in instrumental reason or in a progressive or evolutionary reading of history. Such a bias might well predispose us against mystery, against the aesthetic, the ritualistic, the accidental or path dependent, the neurotic or simply the unknown in our governmental forms. In a similar way, it has been difficult to think of power and knowledge as mutually constitutive or as social and cognitive flows in a constitutionalist framework which names the players and the channels of their interaction.

Most global constitutionalist projects are centered on existing institutional arrangements: the United Nations, or the World Trade Organization or the interactions of national constitutional courts and regimes. There is always the problem of selection. Why these and not others? Are they actually at the 
center? Would things be better if we all treated them as central rather than simply as one more or less significant organization? Each of these institutions carries with it a project and a history - to free trade, to settle disputes, to enforce the peace. They are often worthy projects, but it would be odd to organize governance for the whole around the procedures once thought workable for these more limited aims. Constitutionalizing our existing governance structures does aim to remove them from contestation and revision, harden their division of power and freeze their political and legal players. If all this could be accomplished by interpretation - if we, here, could contribute in some small way to the process by which the world's elites came to think of these institutions in constitutional terms, I do worry about the responsibility we would bear for foreclosing other projects and players and possibilities.

Global constitutionalist discussions also often have a proceduralist bias. It can be very difficult to uncover the substantive biases and political projects of proposals for global governance. They all present themselves in evenhanded terms, as if they were, in fact, drafted behind a veil of ignorance. Sometimes it is easy to see the trick, treating all "states" equally is hardly to be even-handed given the astonishing inequality of states. But more often it takes great work to understand who has been structured to win and who to lose in global legal and institutional arrangements.

At the same time, the entire project of global legal arranging offers itself as innocent of value and ideology and cultural predisposition. All that has been pushed down, below the line of sovereignty, a matter for each local or national community to decide for itself. The international legal order expresses questions of value as "rights" or "principles" which are at least aspirationally universal, treating everything else as an "interest" or an "ideology" of the part, the nation, the region, the culture. To speak substantively places you off the international plane, expressing something we understand to be the interest or attributes of states and organizations and individuals and groups, rather than qualities of the international legal order itself.

We imagine that better procedures will be good for everyone, forgetting that the international order may have a powerful substantive agenda of its own. Focusing on right process, on dispute resolution, on the proper authority of various actors, we forget how much of the status quo we legitimate and how we squeeze those who would change it to the margins of legitimate politics. There is a charming moment in the Kingsbury and Stewart manifesto for better global administrative law when they acknowledge what a generation of law reformers discovered in the development context: improving the machinery of government makes no sense if scoundrels rule - or if the entire global architecture has a substantive skew against the poor, against Russia, against the developing world, against Israel, or whatever. In such a situation, you might well not wish to improve the procedures through which global politics reproduces these tendencies. 
Something similar might be argued about Europe. On one view, the European Union places in private hands the power to ignite the judiciary against national democratic decisions in the name of rules and arrangements largely settled by a transnational technical class. It is not at all clear that constitutionalization of this arrangement will democratize; it may well tip things in quite the other way. At a minimum, we can see that the European legal order affects new and old members differently and brings with it a whole development policy and particular modes of economic and social life. In a similar way, the trade regime entrenches a whole range of distinctions between normal and abnormal traders and trading practices, as well as the hub and spoke bargaining arrangements which characterize bilateral dealing between more and less diversified and developed economies.

Constitutionalism may also bring with it what we might call a "settlement bias." Recasting our situation in constitutional terms can give us the feeling things are settled. The struggle is over and this is how it turned out. Each year, I ask my international law students how they see the project of their generation: is this 1648 or 1918 when the entire order needed to be remade, is it more like 1945 when the system needed to be put back together, reformed, under new leadership, or is it like 1989, when we finally felt all we needed to do was implement, enforce and utilize the international system we had spent so long building in the garage. As you might expect, most usually choose the middle washing machine, precisely as marketing studies would predict. But the number who take the first has grown sharply in the last years, while the number who feel that what the world needs now is more of the same has shrunk to a handful.

Whether we choose to see these as pre-revolutionary times or not, it certainly does seem that the situation is far from settled. Economic, political and cultural competition of many kinds is underway as we confer here. Although the situation may sort itself out peacefully, I expect deep struggles will probably continue, struggles it will be difficult to routinize into the normal institutional politics of one or another constitutional arrangement. Should that happen, I do worry that the constitutionalist frame will encourage us to take our eye off the ball.

\section{CONSTITUtion or No, Global Governance WiLl Be Transformed}

The current appeal of constitutionalism among those who concern themselves with global governance is a puzzle. And it is not just the Europeans either, although we must admit that projects of constitutional governance, like enthusiasm for international adjudication, have become something of a game for intellectuals from the middle powers. It may simply have something to do with the lack of workable maps of global power. We may grab constitutionalist accounts because they are familiar and promise us 
a map, some form of cognitive control over global political life. People may hang on to their favorite constitutional arrangements, down to the institutional details, less because they work as designed even at home, let alone can be expected to do so in the quite different context of global society, than because they are a familiar map and even an inaccurate map from another country can be a comfort when crossing into terra incognita.

Thinking about global governance, I do not think we ought to try to constitute the world anew. There is too much work we still need to do simply to understand how it works, how the forces and factors we have overlooked might be brought into the analysis. We will need to collaborate with many who are not here, place ourselves in a far more global network of research and inquiry, to map the modes of global power and right. Going forward, our most significant contribution to global order may simply be spreading that knowledge, sharing it more evenly, building an academy outside the elite institutions of the North and West where these things are seen as we can see them and encouraging us also to see what can be seen there.

Things like "governance" do change. In Foucault's terms, there was the gallows and then there was the prison timetable. Or, if you prefer, an "economy" can cease to be something to be harnessed for national growth or development and become an international market, facilitating the flow of goods and capital. New ways to govern, new meanings for "politics," new identities for subjects and rulers, for law, for the state, and for things like "culture"-all these things have to be thought up. And when they are built, their power must be wrought into knowledge.

Sometime between 1789 and 1900 - and as late as 1960 for much of the colonial world - governance was consolidated on a global basis around the national sovereign state. People were organized into territorial states, granted citizenship, and government was defined as what national public authorities did. Building a national public politics across the planet had a strong emancipatory dimension - slaves, women, workers, peasants, colonial dominions obtained citizenship in relationship to the new institutional machinery of a national politics. New global governance, called "government," centered on national Parliaments and offered new identities for sovereigns and subjects. Status dissolved into nation and contract. The twentieth century also remade global governance- it was no longer all nations all the time. Law infiltrated the political. Sovereignty, like property, was disaggregated into bundles of rights: corporatism, administration, public/ private partnerships, management. Boundaries eroded, merged. Federalism, power sharing, subsidiarity, devolution. Interdependence, social solidarity, policy management. Here too there were emancipatory elements and important humanitarian accomplishments. But here too there were dark sides and disappointments, just as there were winners and losers. 
We can be confident that global politics will be remade in the twenty-first century. It is just very difficult to say how. There are lots of forces out there which might well turn out to have the revolutionary energy to remake the way we are governed. The emergence of new leadership across Latin America, of tribal nationalism in so many places, of religious fundamentalism in the developed and developing world alike. We might even see the Iraq war as the revolutionary project of a confident American leadership supported by an American middle class experiencing its global vulnerability. The decline of the European project, the rise of China, the erosion of confidence in the West's recipes for humanism and development. Any of these might be the sign of things coming loose.

As they do come loose, I am afraid "constitutionalism" will not be up to the task of holding the fort any more than channeling peaceful change. The conflicts are too real, the status quo too unstable, our current institutions far too wedded to the details of technical management to constitute a new politics. The same, I'm afraid, may be said about proposals for more transparency, accountability, participation, good governance or an improved administrative process. They may remake management of the regime, but not the politics of the globe.

My own hope would be that we might quicken the pace and emotional tenor of decisions in the background institutions of life. Render the forces affecting people's lives more contestable, awaken a sense among actors outside the spotlight of "leadership" and the fishbowl of the international political system that they also govern, that they have discretion, that they can act to change their - and our - institutional arrangements. I have in mind less new procedures than a new spirit of management, encouraging the human experience of responsible freedom throughout the worlds of corporate, private, public and technical expertise.

Our objective would be to carry the revolutionary force of the democratic promise, of individual rights, of economic self-sufficiency, of citizenship, of community empowerment, and participation in the decisions that affect one's life to the sites of global and transnational authority, however local they may be. To multiply the sites at which decisions could be seen and contested, rather than condensing them in a center, in the hope for a heterogeneity of solutions and approaches and a large degree of experimentation, rather than an improved constitutional process or more stable settlement. As we open spaces for conflict and struggle, moreover, we ought to take a break from the search for a universal ethics. Constitutionalism offers an improved institutional platform from which global ethicists can speak for the universal against those who must be cast out from the community of the universal, just when we need conversation, interaction and ethical pluralism.

There are lots of institutional ideas lying around, utopian heuristics for a politics remade. Perhaps the new politics will be about experimentation and 
institutional diversity, protected by a re-activated sovereignty in the middle powers of the South. In such a vision, we might strengthen and defend small pockets of public sovereignty in cities and churches and corporations and nations which have the capacity to experiment, as shields for the weak, guarantors of policy diversity and arenas for democratic political life. Perhaps the new politics will be about mobility. Imagine a grand bargain linking free trade in goods, free movement of capital, with free movement of persons, not only in Europe, where it is easy, but globally. Imagine every person born not only into national citizenship, but with a once in a life time five year visa to the country of their choice.

Or perhaps a new politics will be about building a transnational political will. Imagine sovereignty as an open-ended promise of inclusion, not just a path to membership in the EU for nations along the boundaries who can swallow the whole acquis, but much more. Alberta doing a deal with Montana, New York with Dubai, Palestine finding a place in the European home. Imagine every citizen holding three votes to cast in any election in the world. If the new politics is to be about empowerment, we might imagine citizens not only informed, consulted, their polling data serving as base line for expert management, but actually deciding. Imagine international policy juries - citizens empowered to decide for war or peace, for poverty here or poverty there.

All these may all be terrible ideas. At best they are useful heuristics, reminders of scale and possibility. What we do know is that global governance will be remade over the next century. International law may get the chance to mop up, but I would rather we seized the opportunity to be present at the creation.

Thank you. I look forward to hearing your thoughts. 